\title{
SHELF LIFE STUDY, SENSORY EVALUATION AND NUTRITIVE VALUE OF WHEAT FLOUR/ DASHEEN (Colocasia esculenta (L.) Schott) Taro/Cocoyam FLOUR SWEETBREAD
}

\author{
Maltee R. Rampat ${ }^{1}$, Marsha Singh ${ }^{2}$ and Neela Badrie ${ }^{3 *}$
}

Faculty of Food and Agriculture, The University of the West Indies, Trinidad

1Email: malteerampatm@gmail.com

${ }^{2}$ Email: marsha_ggghotmail.com

33mail: neela.badrie@sta.uwi.edu *(Corresponding author)

\begin{abstract}
The purpose of this study was to develop three variations of taro/dasheen sweetbread with varying percentages of taro flour to replace wheat flour and determine shelf life study, sensory evaluation and proximate composition. Four sweetbread treatments were prepared using wheat flour and taro flour in the ratios W-100: T-0, W70: T-30, W-60: T-40 and W-50: T-50. Each treatment was subjected to a shelf life study for ten consecutive days, tested for colour, $\mathrm{pH}$, water activity, total plate count and to physically observe the two treatments used in the sensory evaluation at air condition temperature of $20^{\circ} \mathrm{C}$ for ten consecutive days. To analyze the results descriptive statistics and statistical tests were used to explore means \pm and standard deviations $(\mathrm{SD})$. Significant difference was established at $(\mathrm{P}<0.05)$. It was concluded that the treatment containing $100 \%$ wheat flour was more preferred, than the sweetbread made with $30 \%$ taro flour to replace wheat flour. However, the ratio W-70: T-30 can produce higher nutritive value than sweetbread made with $100 \%$ wheat flour with similar sensory characteristics. As participants did rate wheat/taro treatment with an affinity of acceptance. The microbiological analysis revealed that sweetbread made from the ratio W-70: T-30 can have a shelf life of approximately one week without growth of bacteria, yeast and moulds. The foregoing ratio of taro flour supplementation can produce sweetbread with superior nutritive value.
\end{abstract}

Keywords: Taro/Dasheen; Sweetbread; Shelf Life; Food Microbiological test; Chemical Food Tests

https://doi.org/10.47412/RWKP8841

\section{Literature Review}

According to Codex Standard 152-1985, wheat flour is the product prepared from grain of common wheat, Triticum aestivum L., or club wheat, Triticum compactum Host., or mixtures thereof, by grinding or milling processes in which the bran and germ are partly removed and the remainder is comminuted to a suitable degree of fineness [1]. The [2] states, "flour" means flour derived wholly or mainly from wheat. [3] stated that wheat contains "gluten" which is a mixture of proteins that occur naturally. [4] outlines that bakery food products are mostly cellular solid food systems which consist mainly of gluten and starch fractions. Sweetbread in Trinidad and Tobago is a popularly known product, made with wheat flour or white flour as its basic ingredient. It is a sweet item which is served as a dessert or snack by Trinbagonians and is commonly sold at bakery outlets. [5] noted "bakery" products are subjected to spoilage problems. 
These include physical, chemical and microbial spoilage. The most common spoilage factor of bakery products is water activity $(a \mathrm{w})>0.85$ and microbiological spoilage, such as moulds". Staling of bakery food products causes a series of reactions which affects the sensory and physical properties. In bakery food products, staling reactions start before microbial deteriorations. Therefore, it is the major factor to determine the shelf life [4]. [6] stated taro/dasheen is extremely useful to persons allergic to cereals and can be consumed by children who are sensitive to milk, as taro/dasheen is rich in vitamin B-complex. Due to its high carbohydrate content, taro/dasheen corms represent one of the main sources of energy in many parts of the tropics and sub-tropics providing about a third of the food intake of more than 400 million people in these specific regions. According to [7] the nutritive value of raw taro/dasheen is that it contains vitamins, minerals, carbohydrates -including fibre, protein and amino acids. Gluten is not listed as a nutrient/protein found in raw taro/dasheen. Based on the foregoing taro/dasheen does not contain gluten. Studies conducted by [8] cited "Taro/dasheen corms can be processed into flour and starch. Taro/dasheen flour produced by the Hawaiian Agricultural Experimental Station stated that it can be used to replace up to 20 percent of the wheat flour in baking". Therefore, the purpose of this study was to develop sweetbread that is superior (nutritionally), with more health benefits to wheat sweetbread by utilizing taro/dasheen flour. Hence, the new kind of sweetbread would stimulate consumer's awareness and interest to try a product that is nutritious.

According to Collins English Dictionary, dasheen is another name for taro and is also known as cocoyam [9]. Webster's College Dictionary states Taro is a stemless plant Colocasis esculenta, of the arum family, cultivated in tropical regions for its edible tuber [10]. In research by [11] it is highlighted that different researchers conclude that it is not possible to determine a single centre of origin for taro. Records from the highlands of Papua New Guinea, indicate that taro processing was active by at least 10000 years, while Alocasia and Colocasia starch residues were noted to be found on stone implements from Buka, Solomon Islands that date back some 28000 years ago. The author concluded that the species is now found throughout the Pacific Islands and worldwide. The two known botanical varieties; Colocasia esculenta (L.) Schott variety esculenta and Colocasia esculenta (L.) Schott variety antiquorum (Schott) Hubbard \& Rehder [12]. [13] further stated that, taro has perhaps been prepared or processed into more consumableforms than any other root crop. The corm is the major economic part of taro which may be roasted, boiled, baked, steamed or fried. Taro corms can be processed into flour and starch. In Western Samoa, taro flour is the starting product for baby-weaning food and taro-based bread. This study has been conducted to determine the effect of partial substitution of taro flour for wheat flour in making sweetbread, the shelf-life, sensory properties and nutritive value.

\subsection{Nutritional/Chemical composition of taro}

Taro a tuber crop, is of great economic importance because of its use as a staple food, highly nutritious and a good source of carbohydrates [14]. The energy from tubers is about one-third of that of an equivalent weight of rice or wheat due to high moisture content of tubers. Nutritional value of tubers varies with variety, location, soil type, and agricultural practices, among others [15]. [16] also outlined taro proximal composition varies depending on the variety, growing conditions, kind of soil, moisture and fertiliser application, maturity at harvest, post-harvest management and storage. In terms of supplying nutrients, besides carbohydrates, potassium and fibre, large servings of taro corms can become a significant source of dietary protein, especially if taken more than once a day. Approximately $11 \%$ of the total protein in taro is albumin with high amounts of phenylalanine and leucine. The protein of taro is well supplied with hundred essential amino acids though low in histindine and lysine. Taro is also a good source of thiamin, riboflavin, iron, phosphorus and zinc and a very good source of vitamin B6, vitamin $\mathrm{C}$, niacin, copper and manganese. Taro also contains greater amounts of vitamin B-complex than whole milk, and it is one of the few non-animal sources of zinc [17]. 


\subsection{Sensory evaluation and consumer acceptance}

[18] states that untrained individuals are employed to determine aroma, taste, appearance, smell, touch and hearing when a new product is developed. These attributes are the organoleptic properties of a food product. Validity and reliability of the consumer testing methodologies are extremely important. Sensory acceptance tests are conducted to identify those products that are significantly disliked and those that match or exceed a specified target product for acceptance. Sensory acceptance tests indicate the acceptance of a product without the package, label, price and so on. The implicit goal of any and all sensory evaluation efforts in the food industry is to enhance quality, to improve appearance, flavor and texture as perceived by consumers which influence their food choices at the point of sale. One of the recommended strategies to assess a concept or new product early in the development stage is by using a focus group.

\subsection{Focus group study}

Focus groups are used to assess consumer acceptability or preference for a certain product through liking and disliking based on the product's attributes, preference of one product over another, the intention of the consumers to use a product and to assess the new ideas [19].

\section{Materials and Methodology}

Mature locally produced taro corms were purchased at the supermarket. The best taro corms (blue variety) were selected based on physical appearance, colour, firmness, free from defects, uniform in shape, size and weight. These were used in the preparation of taro flour. The method for processing taro corms flour was adopted from [20] and modified, as shown in Fig. 2.1 below. The raw taro corms were washed in running water and then peeled. Taro corms were sliced in $4 \mathrm{~mm}$ thickness, immediately arranged on trays in a commercial food dehydrator for 17 hours at $135^{\circ} \mathrm{F}$. The dried taro slices were ground using a grinder until desire finest was achieved, to avoid wastage. The taro flour was immediately packaged in polyethylene bag, labeled and stored at air-conditioned temperature $20^{\circ} \mathrm{C}$ until ready for use. 


\subsection{Processing of taro flour}

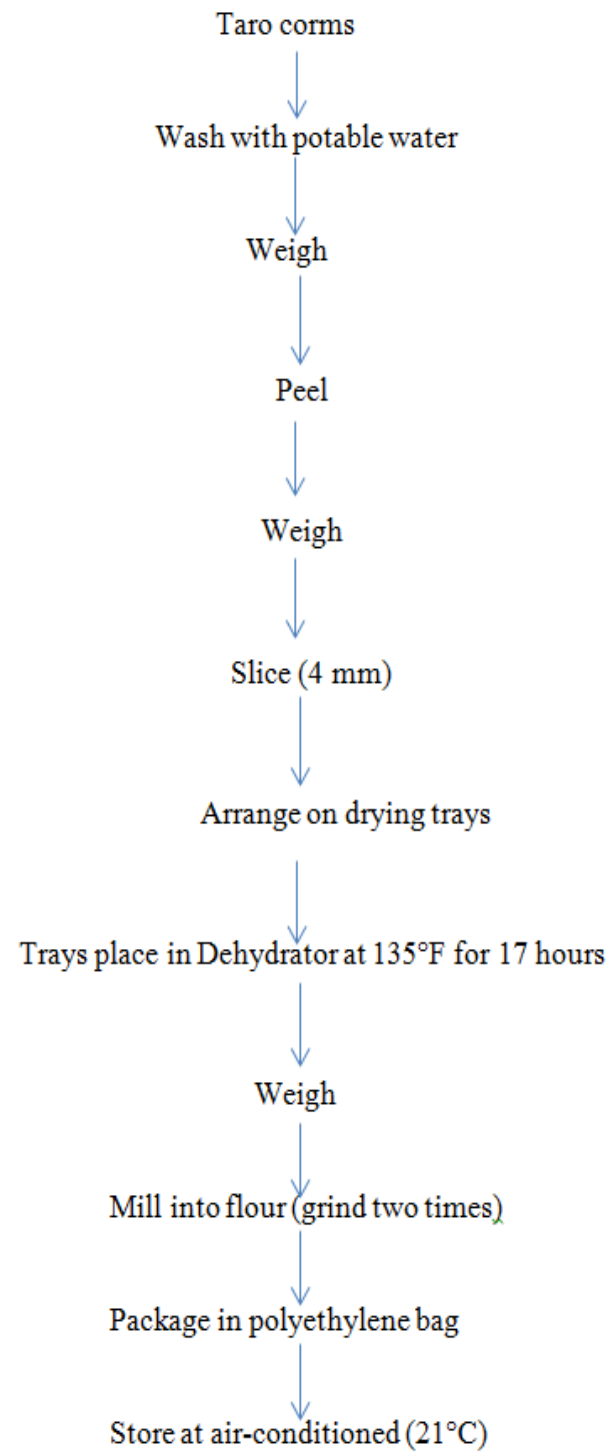

Figure 1: Flow diagram for the processing of taro corms into flour

\subsection{Ingredients used in the preparation of sweetbreads}

A sweetbread recipe was identified from [21] and modified to include dasheen flour. [22] guidelines for preparing the formulation table, flow chart and ratios adopted as shown in Table 1 and Fig 2. Total quantity of ingredients in the whole formulation is 1254 . The amount of taro flour in each treatment is grams of taro flour divided by total quantity of ingredients. The percentages stated in the table below for the two types of flour are based on the entire formulation. 
Table 1: Ingredients used in the preparation of sweetbreads

\begin{tabular}{|l|l|l|l|l|}
\hline \multicolumn{1}{|c|}{ Ingredients } & \multicolumn{5}{c|}{ Samples (g) solids, (ml) liquid } \\
\hline & 555 & 666 & 777 & 888 \\
\hline Wheat flour & $100(484)$ & $\begin{array}{l}70(339) \\
27.03 \%\end{array}$ & $\begin{array}{l}60(290.4) \\
23.16 \%\end{array}$ & $\begin{array}{l}50(242) \\
19.30 \%\end{array}$ \\
\hline Taro flour & 0 & $30(145)$ & $40(193.6)$ & $50(242)$ \\
& & $11.56 \%$ & $15.44 \%$ & $19.30 \%$ \\
\hline Granulated sugar & 200 & 200 & 200 & 200 \\
\hline Margarine & 125 & 125 & 125 & 125 \\
\hline Baking Powder & 15 & 15 & 15 & 15 \\
\hline Yeast & 5 & 5 & 5 & 5 \\
\hline Salt & 0.25 & 0.25 & 0.25 & 0.25 \\
\hline Grated coconut & 100 & 100 & 100 & 100 \\
\hline Water (bottled) & 255 & 255 & 255 & 300 \\
\hline Evaporated milk & 70 & 70 & 70 & 70 \\
\hline
\end{tabular}

Notes: 555: 100\% Wheat flour (W-100: T-0), 666: 70\% Wheat flour and 30\% dasheen flour (W-70: T-30), 777: 60\%

Wheat flour and 40\% dasheen flour (W-60: T-40), 888: 50\% Wheat flour and 50\% dasheen flour (W-50: T-50)

\subsection{Preparation of wheat - taro sweetbreads}

The wheat-taro flour composites were prepared at different ratios (of 100:0, 70:30, 60:40 and 50:50) with other ingredients were weighed accurately as the formulations shown in Table 1. Loaf pans were greased and set aside until ready for use. Melted margarine was prepared just at the point when needed and was incorporated with the other ingredients. The liquids were added to the dried ingredients in the four different sets of measured ingredients to form a batter of thick consistency. Batters were transferred into greased loaf pans, 18-23mmin length and 11-13 mm in height, rectangular shape. The same amount of batter was placed into each loaf pan, in order to maintain uniformity in shape and size. The two-thirds filled loaf pans were placed on the first shelf of a preheated oven at $375^{\circ} \mathrm{F}$ and allowed to bake for 50 to 55 minutes. After baking, the sweetbreads were cooled completely (about 50 minutes) and placed in 'plastic wrap', and labelled 555, 666, 777 and 888 each with the dates and tests to be carried out and stored at air-conditioned temperature $20{ }^{\circ} \mathrm{C}$. 
2.4 Preparation of composite flour (wheat flour: Taro flour) at different ratios

Preparation of composite flour (wheat: taro flour) at different ratios

$(100: 0,70: 30,60: 40$ and 50:50)

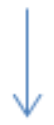

(Sieving) flour and baking powder in four separate mixing bowls

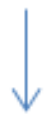

Add sugar, salt, yeast and grated coconut to each of the four bowls

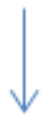

(Mixing) water, essence and melted margarine to all four bowls, gradually

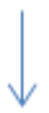

(Filling) greased loaf pans $2 / 3$ full

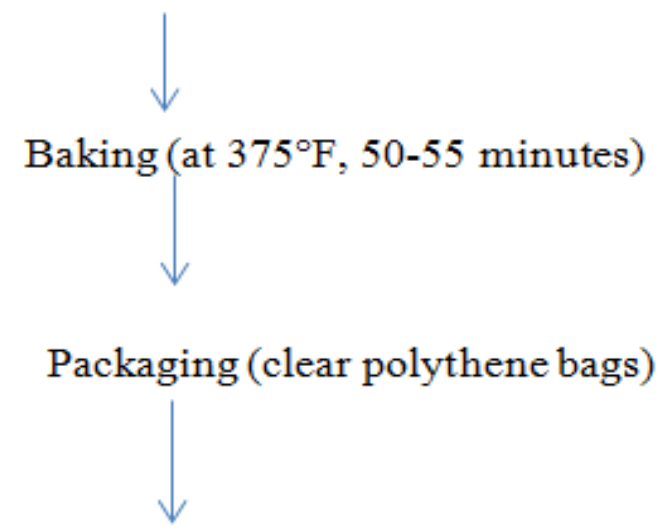

Storage [Air-conditioned temperature $\left(21^{\circ} \mathrm{C}\right)$ ]

Figure 2: Flow diagram for the preparation of sweetbreads

\subsection{Treatments and shelf life study}

The research was designed to be able to evaluate certain quality characteristics such as sensory, physical (instrumental readings), chemical and microbiological aspects of the control and the three variations of wheat to taro flour sweetbreads. Periodic microbiological, water activity, $\mathrm{pH}$ and colour analyses were carried out to assess the shelf life on all four treatments. Also, the control and composite taro/wheat samples 
were placed in polythene transparent zip lock bags and stored at ambient temperature $\left(20^{\circ} \mathrm{C}\right)$ for observation of a period of ten days.

\subsection{Proximate analysis}

The Association of Official Analytical Chemist (AOAC 2005) procedures were used to determine the proximate composition of the treatments/samples. The treatments were analyzed for moisture content, dry matter, ash, ether extract, crude fibre, crude protein and carbohydrate [23].

\subsection{Statistical analysis}

Data collected was entered and analyzed using 'Statistical Package for Social Sciences' (SPSS) version 24.0. Descriptive Statistics were performed on treatments and statistical tests were carried out to explore means \pm and standard deviations $(\mathrm{SD})$. Significant difference was established at $(\mathrm{P}<0.05)$ [24].

\subsection{Sensory evaluation and acceptance}

A focus group session with eight participants was held using all four sweetbread treatments and the two treatments that were most preferred because of taste and texture, the $100 \%$ wheat and $70 \%$ wheat with $30 \%$ taro flour, were used to conduct the sensory evaluation. Fifty untrained panelists were recruited to participate in this sensory evaluation based on age, gender, willingness to participate, time availability, no allergies to the ingredients and interest in the product. The serving of treatments was of the same size, they were labeled/coded 555, 666 and arranged on styro foam plates. Bottled water and sanitary cups were provided to cleanse palate between samples. Participants were asked to taste each sample individually and two paper questionnaires were provided for each participant to complete. Attributes were rated using a traditional 9 point hedonic, where 1 represent "dislike extremely"- the least score and 9 represents "like extremely" - the highest score. How frequent participants would consume the treatments tasted was measured using the Food Action Rating Scale. Scale values 9 represents "I would eat this every opportunity that I had" and 1 represents "I would never eat this only if forced" [25].

\section{Results and Discussion}

The following is the order in which the results and discussions are presented: focus group analysis, proximate analysis of sweetbread treatments, physical evaluation of sweetbread - texture profile; sensory evaluation, the shelf life study and physical observation of treatments stored at air condition/cool air $20^{\circ} \mathrm{C}$.

\subsection{Focus group analysis}

Responses were obtained via the interactive discussion and the questionnaires. All participants stated the product is a good idea. The eight participants do consume sweetbread. Treatments coded 555 and 666 had the same number of likes (4) and same reason for choice, that is taste and texture.

\subsection{Proximate composition of sweetbread treatments}

The results in Table 2 below showed that the control sweetbread is significantly different $(\mathrm{P}<0.05)$ in proximate composition, than the wheat/taro sweetbreads. There were no significant differences in moisture content of the four sweetbread treatments. 
Table 2: Proximate composition of control and composite (wheat/taro) treatments

\begin{tabular}{|l|l|l|l|l|l|}
\hline $\begin{array}{l}\text { Parameters } \\
(\mathbf{g} / \mathbf{1 0 0})\end{array}$ & $\mathbf{5 5 5}$ & $\mathbf{6 6 6}$ & $\mathbf{7 7 7}$ & $\mathbf{8 8 8}$ & P value \\
\hline Moisture content & $2.49 \pm 0.004$ & $3.5 \pm 1.6$ & $2.6 \pm 0.02$ & $2.92 \pm 0.09$ & $\mathbf{0 . 6 4 2}$ \\
\hline Ash content & $17.1 \pm 0.07$ & $18.06 \pm 0.1$ & $18.10 \pm 0.3$ & $20.4 \pm 0.08$ & $\mathbf{0 . 0 0 0}$ \\
\hline Ether Extract & $127.2 \pm 0.51$ & $134.2 \pm 2.5$ & $115.9 \pm 0.65$ & $101.0 \pm 2.41$ & $\mathbf{0 . 0 0 0}$ \\
\hline Crude Fibre & $13.6 \pm 0.3$ & $16.0 \pm 0.05$ & $13.2 \pm 0.08$ & $11.8 \pm 0.11$ & $\mathbf{0 . 0 0 0}$ \\
\hline Crude protein & $77.2 \pm 2.2$ & $59.7 \pm 2.1$ & $56.2 \pm 1.4$ & $52.8 \pm 1.4$ & $\mathbf{0 . 0 0 1}$ \\
\hline Carbohydrates & $765.9 \pm 2.7$ & $774.2 \pm 2.7$ & $794.8 \pm 6.8$ & $810.5 \pm 5.5$ & $\mathbf{0 . 0 0 1}$ \\
\hline
\end{tabular}

Data are averages of triplicate determinations. Differences of means in rows Means ( \pm ) Standard Deviations $(\mathrm{n}=3)$. Notes: 555: 100\% Wheat flour (W-100: T-0), 666: 70\% Wheat flour and 30\% dasheen flour (W-70: T-30), 777: 60\% Wheat flour and 40\% dasheen flour (W-60: T-40), 888: 50\% Wheat flour and 50\% dasheen flour (W-50: T-50)

The results showed that the three treatments which contained taro flour had higher moisture content than the control treatment. According to research by [26] this is due to high water absorption capacity (WAC) of flour made from taro corm than wheat flour. Hence the control had the least moisture content. There was a continuous increase in ash in wheat/taro sweetbread when the increased percentages of taro flour were added to the formulation. [16] stated that ash contains good mineral contents, hence the wheat/taro sweetbread had more mineral content than the sweetbread made with $100 \%$ wheat flour. They further stated that high potassium to sodium ratio food is recommended for patients with high blood pressure. As stated in the introduction of this research paper, the aim is to develop a sweetbread with more nutritional content and health benefits in comparison to a sweetbread that contains $100 \%$ wheat flour. The control sweetbread had lower fat content while treatment 666 (W-70: T-30) recorded an increase and the highest in the wheat/taro sweetbread variations, but studies by [26] stated that although fat content in wheat flour is low, it is higher than that contained in taro flour. Hence, more health benefits can be derived from products that contain taro flour. Also, taro is gluten free. The wheat/taro sweetbread 666 (W-70: T-30) contained 16.03g, the highest crude fibre content whereas crude fibre in the control sweetbread was 13.6g. [16] stated that fibre has many desirable functional properties, just to mention a few: facilitating alimentary functions, helping in micro-component delivery and glucose metabolism, prevent constipation, increase water holding capacity of food. The results showed that crude protein content decreased with the increased supplementation of taro flour. Despite the foregoing, the findings by [16] stated in Section 1.1 of this research regarding the essential amino acids contained in taro must be noted. The results showed that carbohydrate content increased with the addition of taro flour in the three variations of sweetbread. It is concluded that the $100 \%$ wheat sweetbread is significantly different $(\mathrm{P}<0.05)$ from the wheat/taro sweetbread treatments.

\subsection{Physical evaluation of sweetbread}

No significant differences in firmness of texture existed between treatments when tested. 


\subsubsection{Texture profile}

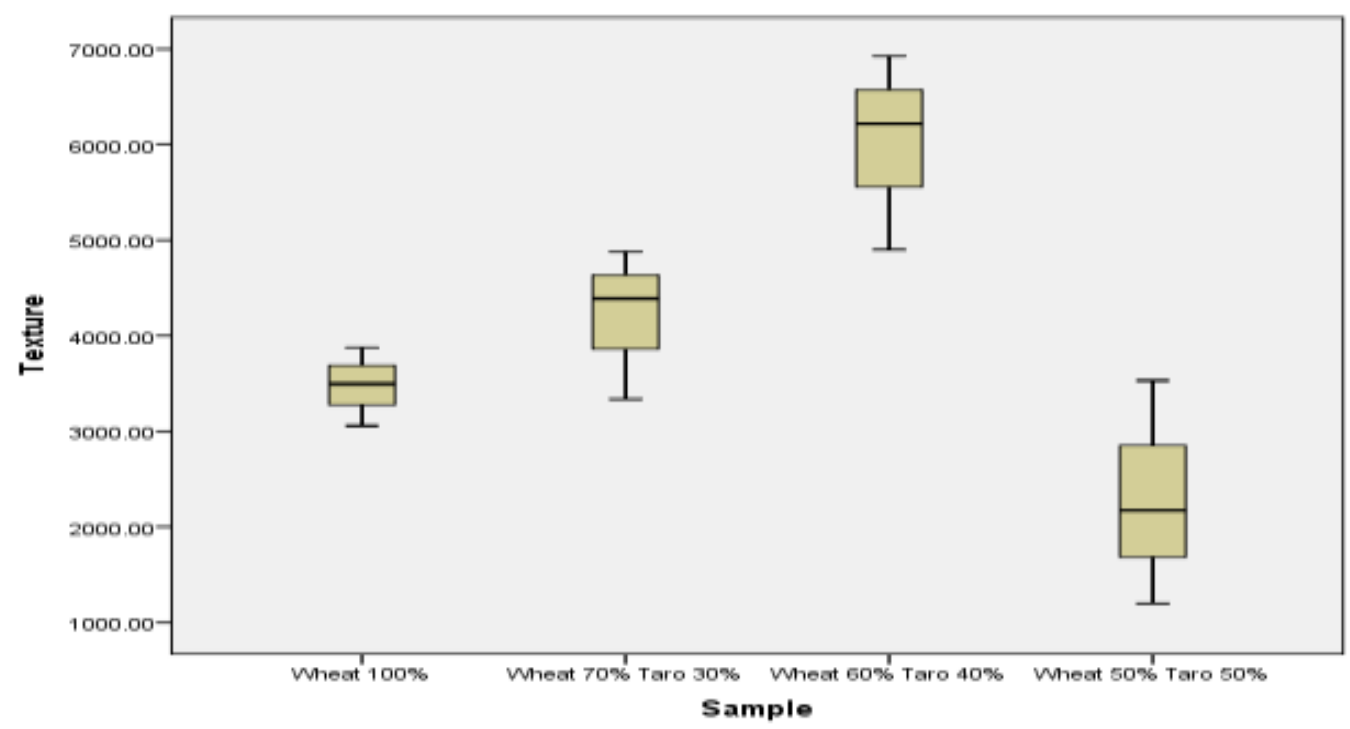

Figure 3: Mean value for firmness of sweetbread treatments

The results in Fig. 3 indicated that all sweetbread treatments showed no significant differences in firmness of texture. Research conducted by [26] on the comparison of functional properties between wheat flour and taro flour stated that the synergic value of these two flours attributed to the differences in amylose content, as starch with high amyl pectin content has been reported to retrograde slowly, due to difference in starch granules size which is smaller for taro starch.

\subsection{Sensory evaluation of sweetbread}

Fifty untrained panelists showed varying levels of likeness in the parameters for both sweetbread treatments shown in the table below.

Table 3: Sensory scores for two sweetbread treatments, values are means and \pm standard deviation.

\begin{tabular}{|l|l|l|l|}
\hline \multirow{2}{*}{ Parameters } & \multicolumn{2}{l|}{ Treatments mean Scores } & \multirow{2}{*}{ P value } \\
\cline { 2 - 3 } & $\mathbf{5 5 5}$ & $\mathbf{6 6 6}$ & \\
\hline Taste & $7.09 \pm 1.84$ & $5.88 \pm 1.70$ & $\mathbf{0 . 0 3 1}$ \\
\hline Mouth feel & $6.97 \pm 1.76$ & $5.56 \pm 2.06$ & $\mathbf{0 . 0 1 6}$ \\
\hline Colour & $7.18 \pm 1.78$ & $6.81 \pm 2.07$ & $\mathbf{0 . 5 2 6}$ \\
\hline Texture & $6.88 \pm 1.59$ & $7.00 \pm 1.21$ & $\mathbf{0 . 7 7 5}$ \\
\hline Flavour & $7.50 \pm 1.58$ & $6.13 \pm 1.50$ & $\mathbf{0 . 0 0 5}$ \\
\hline Overall acceptability & $7.29 \pm 1.56$ & $6.38 \pm 1.31$ & $\mathbf{0 . 0 4 8}$ \\
\hline
\end{tabular}

Notes: 555: 100\% Wheat flour (W-100: T-0), 666: 70\% Wheat flour and 30\% dasheen flour

It is concluded from the results above that the parameters of taste, colour, flavour and overall acceptability in the control treatment were most preferred by participants. The mean scores in all four sensory attributes 
of the control relates "like moderately" and for wheat/taro mean scores of the said parameters relates "like slightly" and "neither like nor dislike". Mean scores of both, mouth feel and texture relates "like slightly" for the control treatment, although the mean score for texture was higher than the control.

\subsection{Shelf life study}

For colour no significant differences $(\mathrm{P}<0.05)$ existed when ANOVA tests were conducted for all four treatments, over five days. The tests for water activity showed high significance $(\mathrm{P}<0.05)$ in all the sweetbread treatments, the mean scores ranged from 0.89 to 0.92 , which will lead to spoilage as stated in the "Literature Review" above. The mean scores of $\mathrm{pH}$ for all four treatments were close to a neutral state for day 1, 3 and 5 as no major differences were recorded. For the microbiological period of ten consecutive days, colony forming units (CFU) were too few to count (TFTC). However, there was contamination that appeared to be cloudy on the petri dish at certain replicates. The two sweetbread treatments used to conduct the sensory evaluation and were stored at air condition/cool air temperature of $20^{\circ} \mathrm{C}$ showed no main signs of deterioration or bad odour, for eight consecutive days. By day 9, very small, mild dark patches (possibility of moulds such as aspergillus and rhizopus) were observed on the two slices of the treatment, $100 \%$ wheat flour (555), and 70\% wheat flour/30\% taro flour (666). On the last day of physical observation day 10, microbiological growth was evident and clear indication that the sweetbread slices had deteriorated and were no longer suitable for consumption, more than any of the previous days. The control treatment (555) appeared to have a black discolouration unlike the wheat/taro (666) treatment. Also, both slices seemed to have a similar type of bacteria growth which looks greyish/greenish, besides the additional black colouration seen on the control treatment. There may be the possibility that the control treatment deteriorated more than the taro/wheat treatment. Both slices were dry and very firm in texture. There was no significant odour of spoilage of the two treatments on day 10.

\section{Conclusion}

The overall objective of this study was met, thoroughly investigated and the conclusion is that the sweetbread treatment containing $100 \%$ wheat flour was more preferred to the sweetbread made with $30 \%$ taro flour replacement. However, sweetbread made up-to using $30 \%$ taro flour substitution produced higher nutritive value in minerals, carbohydrates and fibre, than sweetbread made with $100 \%$ wheat flour and can have similar sensory characteristics when compared. Therefore, a sweetbread with superior nutritional value was recorded, also "like slightly" and "neither like nor dislike" were determined. The microbiological analysis revealed that both sweetbread treatments had the same shelf life of approximately one week without growth of bacteria, yeast and moulds. In conclusion sweetbread prepared by supplementing $30 \%$ taro flour to replace wheat flour was superior in minerals, crude fibre and carbohydrates.

\section{References}

[1] Codex Standard 152-1985 Adopted 1985. Revision 1995, Codex standard for wheat flour. [2] Flour and Wheatenmeal Act 1956., Part 1, Section 3 (1) Faolex.fao.org/docs/texts/ /ire20954.doc. [3] FDA (U.S. Food \& Drug Administration). 2018. "CFR - Code of Federal Regulations Title 21." Vol. 2.21CFR101.91

[4] S. Nesli, K. L.Jozef, B. Rieks, D. Christie, F. William, T. Bob, and H. Sue. 2009. "Quality Improvement Project for Shelf Stable Bakery Products." Abstract. The School of Environmental and Biological Science Rutgers, The State University of New Jersey New Brunswick, New Jersey 08903. [5] Saranraj and Geetha $(2011,2)$ Microbial Spoilage of Bakery Products and Its Control by Preservatives -Review Article. Department of Microbiology, Annamalai University, Annamalai Nagar, Chidambaram 608002, International Journal of Pharmaceutical \& Biological Archives 2012;3(1): 38-48.

[6] Alcantara, R. M., W. A. Hurtada, and E. I. Dizon. 2013. "The Nutritional Value and Phytochemical Components of Taro [Colocasia esculenta (L.) Schott] Powder and its Selected Processed Foods." 
Journal of Nutrition and Food Sciences 3:207. doi:10.4172/2155-9600.1000207.

[7] United States Department of Agriculture (USDA). 2018. Nutritive value of raw taro. [8] Palomar, L. Salares 1986. The inhibition of Growth and Mycotoxin Production in a Taro-Based Food Product (Binagol, Cinnamon, Potassium-Sorbate, Natamycin, Aflaxtoxin). The University of NebraskaLincoln Proquest Dissertation Publishing, 8614469.

[9] Collins English Dictionary 2014. "Definition of dasheen" The Free Dictionary by Farlex. [10] Webster's College Dictionary 2010. "Definition of Taro". The Free Dictionary by Farlex. [11] Temesgen, M. and Ratta, N. (2015). "Nutritional potential, Health and Food Security Benefits of Taro Colocasia esculenta (L.): A Review" Aug 1, 2018 - Article (PDF Available) in The Open Food Science Journal.

[12] FAO (Food and Agriculture Organization of the United Nations). 1999. Composition of Taro corm and Leaf.

[13] Palomar, L. Salares 1986. The inhibition of Growth and Mycotoxin Production in a Taro-Based Food Product (Binagol, Cinnamon, Potassium-Sorbate, Natamycin, Aflaxtoxin). The University of NebraskaLincoln Proquest Dissertation Publishing, 8614469.

[14] Babu, B., Hegde, V., Kumar, M. and Jeeva., M.L. 2011. "Detection and Identification of Dasheen mosaic virus Infecting Colocasia esculenta in India." Indian Journal of Virology 22(1): 59-62. [15] Chandrasekara, A., and Kumar, T., J., 2016. "Roots and Tuber Crops as Functional Foods: A Review on Phytochemical Constituents and Their Potential Health Benefits." International Journal of Food Science, Volume 2016, Article ID3631647.

[16] Temesgen, M. and Ratta, N. (2015). "Nutritional potential, Health and Food Security Benefits of Taro Colocasia esculenta (L.): A Review" Aug 1, 2018 -Article (PDF Available) in The Open Food Science Journal.

[17] Alcantara, R. M., W. A. Hurtada, and E. I. Dizon. 2013. "The Nutritional Value and Phytochemical Components of Taro [Colocasia esculenta (L.) Schott] Powder and its Selected Processed Foods." Journal of Nutrition and Food Sciences 3:207.doi:10.4172/2155-9600.1000207.

[18] Brody, A.L. and Lord J.B. 2007. "Developing New Food Products For A Changing Market Place", $2^{\text {nd }}$ Ed.365-366; 368 CRC Press Taylor and Francis Group.

[19] Sharif, M. K., Butt, M. S., Sharif H.R. and Nasir M. 2017. "Hanbook of Food Science and Technology, Chapter 14: Sensory Evaluation and Consumer Acceptability, pp 362-386"

[20] Sharmar, H.K., Njitang, N. Y., Singhal, R., S. and Kaushal P. 2016. "Tropical Roots and Tubers, Production, Processing and Technology” 330-333. Institute of food Science Technology. John Wiley and Sons Limited.

[21] Nestle Trinidad Food Products Limited. 1989. "Tried and True Recipes from Carnation, Breads and Cakes p.6.

[22] Toan, N. V. and Thanh P.T. 2018. "Preparation and improved quality production of flour and the made biscuits from the taro" International Journal of Food Science and Nutrition ISSN: 2455-4898 Impact Factor: RJIF 5.14, Volume 3; Issue 5; Page No. 71-79.

[23] AOAC (Association of Official Analytical Chemist). 2005. Official Methods of Association of Official Analytical Chemist. 18th edition, Gaithersburg USA.

[24] N.H. Nie, D.H. Bent and C.H. Hull 1968. In 1975, SPSS was incorporated with the SPSS Incorporation's headquarters located in Chicago (Ill., USA) [1] [25] Singh-Ackbarali., D. and Maharaj R. 2014. "Sensory Evaluation as a Tool in Determining Acceptability of Innovative Products Developed by Undergraduate Students in Food Science and Technology at The University of Trinidad and Tobago." Journal of Curriculum and Teaching Vol.3, No. 1.doi:10.5430/jct.v3n1p10.

[26] Hossain B. 2016. Effect of Taro Flour Addition on the Functional and Physiochemical Properties of Wheat Flour and Dough for the Processing of Bread. Nutrition and Science International food Journal, Research Article Vol.1 issue 2, 2016. 